\title{
PENGARUH KUALITAS PELAYANAN DAN KEPERCAYAAN MEREK TERHADAP LOYALITAS KONSUMEN DENGAN KEPUASAN KONSUMEN SEBAGAI VARIABEL INTERVENING PADA HIJAB MEDYNA COLLETION SITUS SHOP ONLINE
}

\author{
Nadifatul Lailiyah \\ Mahasiswa Magister Manajemen Pascasarjana Universitas Islam Malang \\ Email : nadif4921@gamil.com
}

\begin{abstract}
Abstrak
Penelitian ini bertujuan untuk mengetahui faktor- faktor yang mempengaruhi profitabilitas dengan Kualitas konsumen dan Kepercayaan merek Loyalitas konsumen sebagai variabel $\mathrm{Y}$, Kepuasan konsumen sebagai variabel intervening. Alat analisis pada penelitjian ini adalah Analisis Path. Sampel dari penelitian ini adalah 95 jumlah orang member atau reseler yang beli di toko hijab medyna colletion malang. Metode pengumpulan data yang digunakan adalah kuesioner (angket). Analisis yang digunakan meliputi Uji istrumen, Uji normalitas, Analisis data, Uji hipotesis, Uji t dan Uji sobel. menggunakan analisis regresi linier berganda dengan bantuan software SPSS 17.0 for windows.

95 breseler atau member medyna colletion yang menjadi populasi penelitian ini, hasil penelitian menunjukkan bahwa Kualitas pelayanan, Dan kepuasan merek Berpengaruh langsung terhadap Kepuasan konsumen, terdapat pengaruh positif dan signifikan. Kualitas Pelayanan, Dan kepercayaan merek Berpengaruh langsung terhadap Loyalitas konsumen, terdapat pengaruh positif dan signifikan. Kepuasan konsumen Berpengaruh langsung terhadap Loyalitas konsumen, terdapat pengaruh positif dan signifikan Kepercayaan merek terhadap kepuasan konsumen. Semakin baik kepercayaan merek maka kepuasan konsumen akan semakin meningkat atau sebaliknya semakin tidak baik kepercayaan Merek maka kepuasan konsumen akan semakin menurun. Kualitas Pelayanan dan Kepercayaan merek secara tidak langsung Berpengaruh terhadap Loyalitas konsumen dengan Kepuasan konsumen, Pengaruh positif dan signifikan kualitas pelayanan terhadap Loyalitas konsumen. Semakin baik kepercayaan merek maka Loyalitas konsumen akan semakin meningkat atau sebaliknya semakin tidak baik kepercayaan merek maka Loyalitas konsumen akan semakin menurun.
\end{abstract}

Kata kunci: Kualitas pelayanan, Kepercayaan merek, Loyalitas konsumen dan Kepuasan konsumen

\footnotetext{
Abstract

This study aims to determine the factors that influence profitability with consumer quality and brand trust Consumer loyalty as $Y$ variable, customer satisfaction as an intervening variable. The analytical tool in this research is Path Analysis. The sample from this study was 95 number of members or resellers who bought at the poor hijab medyna colletion shop. The data collection method used is a questionnaire. The analysis used includes test instrument, normality test, data analysis, hypothesis test, t-test and sobel test using multiple linear regression analysis with the help of SPSS 17.0 for Windows software.

95 resellers or members of medyna colletion which became the population of this study. The results of the study indicate that service quality, and brand satisfaction directly influence consumer satisfaction, there are positive and significant influences. Service Quality, and also brand trust directly influences consumer
} 
loyalty, this result means that there are positive and significant influences. Consumer satisfaction has a direct effect on consumer loyalty, there is a positive and significant influence on brand confidence in customer satisfaction. The better brand trust, customer satisfaction will increase or vice versa, the less trust the brand will, the more customer satisfaction will decline. Service Quality and brand trust indirectly influence consumer loyalty with consumer satisfaction, positive and significant influence on service quality on consumer loyalty. The better the brand trust, the consumer loyalty will increase or otherwise the worth the brand trust, the consumer loyalty will decrease.

Keywords: Service quality, Brand Trust, Consumer Loyalty and Consumer Satisfaction.

\section{PENDAHULUAN}

Kemajuan teknologi, khususnya internet membuat keterbatasan jarak, waktu, dan biaya dapat terasi dengan mudah. Implementasi teknologi dalam hal meningkatkan bisnis, penjualan dan pembelian produk adalah dengan menggunakan electronic commerce (ecommerce), (Spica, 2007 dalam Adi, 2013).

Factor lain yang juga mempengaruhi keputusan pembelian yaitu kepuasan konsumen. Konsumen yang merasa puas terhadap lingkungan internet secara keseluruhan akan cenderung percaya terhadap website yang menyediakan pelayanan perdagangan eloktronik (electronic commerce). Pada Secara umum, konsep kemanan mengacu kemampuan dari website perusahaan online untuk melindungin informasi konsumen dan data transaksi keuangan mereka dicuri selama terjadi hubungan diantara mereka. Park dan Kim (2006) mendefinisikan security atau keamanan sebagai kemampuan online dalam hubungan melakukan pengeontrolan dan penjagaan keamanan atas transaksi data.

Dalam penelitian ini tentang pengaruh loyalitas konsumen terhadap pembelian secara online pada konsumen di toko hijab mendyna collettion, mengatakan bahwa loyalitas konsumen lebih tinggi terjadi pada transaksi pembelian online dari melakukan pembelian melalui toko offline. Apabila tingkat resiko yang tinggi akan membuat konsumen tidak nyaman dalam menggunakan e-commerce. Loyalitas konsumen inilah yang kemudian mempengaruhi konsumen dalam melakukan transaksi pembelian melalui online shop.

Berdasarkan indifikasi permasalahan di atas maka tujuan dari penelitian ini adalah untuk mengetahui :

1. Untuk mengetahui Kualitas pelayanan dan Kepuasan merek Berpengaruh langsung terhadap Kepuasan konsumen di toko hijab medyna colletion Malang?

2. Untuk Mengetahui Kualitas Pelayanan dan Kepercayaan merek Berpengaruh langsung terhadap Loyalitas konsumen di toko hijab medyna colletion Malang?

3. Untuk mengetahui Kepuasan konsumen Berpengaruh langsung terhadap Loyalitas konsumen di toko hijab medyna colletion Malang?

4. Untuk mengetahui Kualitas Pelayanan dan Kepercayaan merek secara tidak langsung Berpengaruh terhadap Loyalitas 
konsumen dengan Kepuasan konsumen sebagai Variabel intervening?

\section{KAJIAN TEORI \\ Pengertian Kualitas pelayanan}

Salah satu factor yang menentukan tingkat kebersilan dan kualitas perusahaan, menurut John Sviokla, adalah kemampuan perusahaan dalam memberikan pelayanan kepada pelanggan. Keberhasilan perusahaan dalam memberikan layanan yang berkualitas kepada para pelanggannya, pencapaian pangsa pasar yang tinggi, serta peningkatan laba perusahaan tersebut sangat ditentukan oleh pendekatan yang digunakan (Zeithmal, Valerie A., Mary jo Bitner Dan Dawayne D. Gemler. 20013:151). Konsekuensi atas pendekatan kualitas suatu produk memiliki esensi penting bagi strategi perusahaan untuk mempertahankan diri dan mencapai kesuksesan dalam menghadapi persaingan.

Menurut Parasuraman, Zeithmal, dan Berry (2011: 118), di simpulakn bahwa dari kelima dimensi tersebut terdapat kepentingan relative berbeda-beda. Kehandalan dalam hal ini secara konsisten meruapakan dimensi yang paling kritis, kemudian pada tingkat ke dua diduduki oleh kepastian, ketiga oleh keberwujudan, dan dimensi terakhir yang memiliki kadar kepentingan paling rendah, yaitu emapti. Sedangkan indicator indicator variable kualitas pelayanan di ukur dengan menggunakan skala Likert menurut Maulina Hardiyanti, 2012 adalah sebagai berikut: (1) kemudahan dalam kepercayaan akses (2) pelayanan yang baik (3) member nformasi (4) kemanan produk (5) merespon keluhan (6) produk bias di andalkan.

\section{Kepercayaan Merek}

Kepercayaan adalah kemauan seseorang untuk bertumpu pada orang lain dimana kita memiliki keyakinan padanya. Kepercayaan merupakan kondisi mental yang didasarkan oleh situasi seseorang dan konteks sosialnya. Ketika seseorang mengambil suatu keputusan, ia akan lebih memilih keputusan berdasarkan pilihan dari orang- orang yang lebih dapat ia percaya dari pada yang kurang dipercayai (Moorman, 1993:82)

Ketika seseorang mengambil suatu keputusan, maka akan lebih memilih keputusan berdasarkan pilihan dari orang orang yang lebih dapat dipercayai. Dan variable percayaan diukur dengan menggunakan skala Likert. Berikut adalah indicator-indikator variable kepercayaan menurut Maulina, 2012: (1) Kreibilias, (2) Keandalan penjual, (3) Kepedulian, (4) Kompensasi kerugian, (5) Kejujuran penjualan. (6) kejujuran dalam melayani.

\section{Loyalitas Pelayanan konsumen}

Konsumen yang akan membawa dampak baik bagi sebuah perusahaan adalah konsumen yang loyal terhadap produk perusahaan tersebut. Konsumen yang loyal akan membawa sebuah keuntungan jangka panjang bagi perusahaan. Dengan adanya pembelian secara berulang dari konsumen, maka keuntungan yang didapatkan oleh perusahaan tersebut akan berjalan seiring dengan adanya pembelian yang dilakukan oleh konsumen. 
Menurut Griffin dalam Sangadji dan Shopiah (2013:104), menyatakan bahwa: "loyalty is defined as non random purchase expressed over timed by some decision making unit". Berdasarkan definisi tersebut dapat dijelaskan bahwa loyalitas lebih mengacu pada wujud perilaku dari unit-unit pengambilan keputusan untuk melakukan pembelian secara terusmenerus terhadap barang atau jasa dari suatu perusahaan yang dipilih.

\section{Kepuasan konsumen}

Pengertian kepuasan menurut Kotler dan Keller (2009:138) adalah perasaan senang atau kecewa seseorang yang timbul karena membandingkan kinerja yang dipersepsikan produk (atau hasil) terhadap ekspetasi mereka. Sedangkan menurut Umar (2008:65) kepuasan konsumen adalah tingkat perasaan konsumen setelah membandingkan antara apa yang dia terima dan harapannya.

Perusahaan dalam memproduksi suatu produk atau jasa berharap bahwa produk tersebut dapat memenuhi kebutuhan konsumen sekaligus memuaskan konsumen.Kepuasan konsumen merupakan hal yang ingin diperoleh oleh perusahaan di samping memprioritaskan laba sebagai tujuan perusahaan.Apabila konsumen merasa puas dengan produk yang dibeli dari sebuah perusahaan, maka kemungkinan untuk melakukan pembelian ulang akan bertambah sehingga perusahaan akan mendapatkan keuntungan.

Dan variable percayaan diukur dengan menggunakan skala Likert. Berikut adalah indicator-indikator variable kepuasan konsumen menurut Maulina, 2012: a. Anda puas dengan model. b. Nyaman saat memakai. c. Anda merasa puas dengan harga. d. Membeli sepatu berdasarkan pengalaman orang lain. e. Karena sesuai dengan kebutuhan. f. Pelayanan medyna Colletion sesuai dengan yg di harapkan.

\section{Hubungan Antar Variabel}

1. Hubungan Kualitas pelayanan Dengan Kepuasan konsumen

Kualitas pelayanan kemampuan suatu perusahaan dalam memenuhi harapan konsumen dengan memberikan pelayanan kepada konsumen pada saat berlangsung dan sesudah transaksi berlangsung. Kepuasan konsumen perasaan senang atau kecewa seseorang yang muncul setelah membandingkan kinerja hasil produk yang dipikrkan terhadap kinerja yang diharapkan

2. Hubungan Keprcayaan merek Dengan Kepuasan konsumen

Menurut Baskara et al., (2014:2) "bahwa factor kepercayaan menjadi factor yang paling dipertimbangkan dalam setiap jual beli khususnya pada pembelian produk dan jasa secara online".

Sedangkan menurut Kotler (2003:61) bahwa kepuasan pelanggan adalah persepsi seseorang atas kinerja suatu produk atau pelayanan yang di rasakan dibandingkan dengan harapan yang dimiliki oleh konsumen, dimana dengan adanya kepuasan pelanggan makan akan menimbulkan kepuasan konsumen.

3. Hubungan Kualitas pelayanan Dengan Loyalitas konsumen

Kualitas pelayanan merupakan factor utama yang mempengaruhi loyalitas konsumen dikarenakan konsumen yang terpuaskan pelaynanannya akan memiliki loyalitas konsumen yang 
tinggi terhadap perusahaannya. Dengan konsumen sering kali tidak loyal disebabkan oleh adanya pelayanan yang buruk atau kualitas pelayanan yang semakin menurun dari yang diharapkan konsumen. Penelitian ini dilakukan oleh Hygid Starini (2013:34)menyatakan bahwa kualitas pelayanan berpengaruh positif dan dan signifikan terhadap loyalitas konsumen.

4. Hubungan Kepercayaan merek Dengan Loyalitas konsumen

Merek adalah berkaitan dengan kepercayaan konsumen terhadap suatu merek.dimana konsumen akan melihat dari merek yang ingin mereka percaya, yaitu reputasi dari merek tersebut apakah baik atau tidak, kemampuan dari merek tersebut memenuhi harapan para konsumennya. Apabila suau merek dapat melakukan hal tersebut maka konsumen secara tidak langsung akan menjadi loyal terhadap merek tersebut. Dengan merek yang telah sesuai dengan konsumen tersebut maka selanjudnya konsumen akan percaya terhadap merek tersebut yang kemudian tercipta juga sikap loyal merek tersebut (Riana, 2008:192).

5. Memiliki konsumen yang loyal adalah tujuan akhir dari semua perusahaan. Dan untuk membentuk sebuah loyalitas, perusahaan perlu memperhatikan kualitas pelaynanan yang dapat memberikan suatu dorongan kepada knsumen untuk menjalin ikatan hubungan yang kuat dengan perusahaan. Sedangkan menurut Umar (2008:65) kepuasan konsumen adalah tingkat perasaan konsumen setelah membandingkan antara apa yang dia terima dan harapannya.

\section{METODE PENELITIAN}

Metode penentuan sampel yang digunakan dalam penelitian ini adalah metode sampel jenuh.Metode sampel jenuh adalah teknik penentuan sampel bila semua anggota populasi digunakan menjadi sampel.

\section{Populasi Dan Sampel}

Menurut Usman (2006:181) Populasi dalam setiap penelitian harus di sebutkan dalam secara tersarat yaitu yang berkenan dengan esarnya anggota populasi serta wilayah penelitian yang disebutkan secara tersurat yaitu yang berkenan dengan besarnya anggota populasi serta wilayah penelitian yang dicakup.

Adapun jumlah populasi dalam penellitian ini untuk pemblian hijab di medyna colletion shop online yaitu 95 orang member/reseler yang tetep ke toko Hijab Medyna Colletion Malang.

Sampel adalah bagian dari populasi (sebagai atau wakil populasi yang diteliti).Sampel penelitian adalah sebagian dari populasi yang di ambil sebagai sumber data dan dapat mewakili seluruh populasi.Adapun penentuan jumlah sampel yang digunakan oleh penulis dalam penelitian ini adalah dengan metode sensus berdasarkan pada ketentuan yang dikemukakan oleh Sugiyono (2002:61-63), yang mengatakan bahwa: Sampling jenuh adalah teknik penentuan sampel bila semua anggota populasi digunakan sebagai sampel. Istilah lain dari sampel jenuh adalah sensus. 


\section{Definisi Variabel}

Kualitas pelayanan (X1)

Menurut Kotler (2012), menyatakan kunci utama mempertahankan pelanggan adalah dalam Pelayanan pembelian hijab. Indikator kepuasan pelanggan dapat dilihat dari :

a. Kemudahan dalam pelayanan akses b. Pelayanan yang baik $\mathrm{c}$. memberi informasi d. kemanan produk e. merespon keluhan $f$. Produk biasa di andalkan.

Kepercayaan merek (X2)

Indikator digunakan untuk mengukur kepercayaan merek adalahkemauan seorang untuk bertumpu punya keyakinan dalam pada membelian hijab, indikator yang disebut oleh Maulina Haryanti (2012) yang terdiri:

a. Kualitas produk b. Citra penjual online c. Bukti transaksi melalui nomor resi pe-ngiriman. d. Terjaminnya transaksi e. Kemudahan transaksi melalui COD f. Ramah dalam tanggapan

Kepuasan konsumen $(Z)$

Menurut Kotler (2012), adalah perasaan senang atau kecewa seseorang yang timbul karena membandingkan kinerja yang dipersiapkan produk terhadap ekspetasi mereka. Indikator kepuasan pelanggan dapat dilihat dari :

a. Anda puas dengan model.b. Nyaman saat memakai. c. Anda merasa puas dengan harga. d. Membeli sepatu berdasarkan pengalaman orang lain. f. Karena sesuai dengan kebutuhan.Pelayanan medyna Colletion sesuai dengan yg di harapkan

Loyalitas konsumen( $\mathrm{Y}$ )

Indikator menurut Suryani (2008:115), konsumen yang loyal pada produk perusahaan tersebut. dan indikatornya sebagai sebagai berikut:

a. Kecurigaan akan penipuan b. kualitas produk c. Kesesuaian harga d. Kepuasan produk e. Perbandingan harga dengan sesuai produk f. Terjamin kualitas produk

\section{Uji Instrumen}

Uji validitas dapat dilakukan dengan membandingkan nilai $r$ hitung dengan $r$ table untuk degree of freedom $(\mathrm{df})=\mathrm{n}-2$, dalam hal ini $\mathrm{n}$ adalah jumlah sample. Untuk menguji apakah masing-masing pernyataan valid atau tidak dapat dilihat dari nilai $r$ hitung, dan $r$ tabel. Jika $r$ hitung lebih besar dari $r$ tabel, dan nilainya positif maka pertanyaan tersebut dinyatakan valid. Jika nilai semua $r$ hitung di atas $r$ tabel maka dapat disimpulkan semua indikator valid.

\section{Uji Reliabilitas}

Reliabilitas adalah sesuatu instrumen cukup dapat dipercaya untuk digunakan sebagai alat pengumpulan data karena instrument tersebut sudah baik (Arikunto, 2010). Pengukuran reliabilitas dalam penelitian ini dilakukan dengan cara one shot atau pengukuran sekali saja. Disini pengukurannya hanya sekali, dan kemudian hasilnya dibandingkan dengan pertanyaan lain atau mengukur korelasi antar jawaban pertanyaan. SPSS memberikan fasilitas untuk mengukur reliabilitas dengan uji statistik 
Cronbach Alpha ( $\alpha$ ). Suatu variabel dikatakan reliabel jika memberikan nilai Cronbach Alpha> 0.70. (Nunallly dalam Ghozali, 2011:48).

\section{Uji Normalitas}

Uji normalitas bertujuan untuk mengetahui data yang terus menerus sahihnya itu normal atau tidak, data yang normal selanjutnya bisa di analisis dengan metode product moment person, dan data yang tidak normal diselanjutnya di ukur melalui metode rank spearman, kebanyakan data yang diteliti untuk konsentrasi manajemen keuangan ini pasti normal, contoh kalimat penyusunan uji normalitas. Agar data-data yang diperoleh dalam penelitian ini dapat dipertanggung jawabkan, terlebih dahulu harus diuji normalitasnya.Hal ini penting untuk mengetahui apakah data yang diperoleh dalam penelitian tersebut normal atau tidak. Menurut Sugiyono (2008;295)

a. $\mathrm{H} 0$ diterima dan $\mathrm{H} 1$ ditolak jika $\mathrm{F} \leq \mathrm{F}$ table, artinya variabel bebas (x) secara simultan tidak berpengaruh secara signifikan terhadap variabel terikat $(\mathrm{y})$.

b. H0 diterima dan $\mathrm{H} 1$ ditolak jika $\mathrm{F} \geq \mathrm{F}$ table, artinya variabel bebas $(x)$ secara simultan tidak berpengaruh secara signifikan terhadap variabel terikat $(y)$.

\section{Analisis Data}

Metode analisis yang digunakan untuk menguji hipotesis dalam penelitian ini menggunakan teknik analisis jalur (path analysis) yang terstandarisasi dan dihitung melalui program SPSS. Jadi path analysis digunakan untuk menganalisis pola hubungan antar variabel dengan tujuan untuk mengetahui pengaruh langsung maupun tidak langsung seperangkat variabel bebas (eksogen) terhadap variabel terikat (endogen).

\section{Uji Hipotesis}

\section{Uji t (t-test)}

Pengujian ini bertujuan untuk mengetahui apakah setiap variable bebas berpengaruh secara signifikan terhadap variable terikat pada tingkat derajat keyakinan tertentu. $\mathrm{H}_{0}$ diterima, bila t-tabel > t-hitung, berarti tidak ada pengaruh yang signifikan dari variable bebas terhadap variable terikat. $\mathrm{H}_{0}$ diterima, bila t hitung $>\mathrm{t}$-tabel berarti ada pengaruh yang signifikan dari variable bebas terhadap variable terikat (Aisyah, 2010).

\section{Uji Sobel}

Pengujian ini bertujuan untuk mengetahui pengaruh mediasi yang ditunjukan dengan perkalian koefisien ( $\mathrm{P}$ Independen $\mathrm{XP}$ mediasi). Uji sobel dilakukan dengan cara mengujih kekuatan pengaruh tidak langsung variable $(X)$ kepada variable $(Y)$ melalui Intervening $(Z)$. pengaruh tidak langsung $X$ ke $Y$ melalui $Z$ ke $Y$ (b) atau ab. Jadi koefisien $a b=(c-c ")$, dimana $c$ adalah pengaruh $X$ terhadap $Y$ tanpa mengontrol $Z$, sedangkan $c$ " adalah koefisien pengaruh $X$ ke $Y$ setelah mengontrol $Z$. 
Standar eror koefisien a dan b ditulis dengan $\mathrm{Sa}$ dan Sb, besarnya standar eror tidak langsung (Independent effect) Sab di hitung dengan rumusan berikut ini:

$$
\mathrm{Sab}=\sqrt{b^{2}+s a^{2}+a^{2}} b a^{2}+s a^{2} S b^{2}
$$

Untuk mengujih signifikasi pengaruh tidak langsung mka kita perlu menghitung nilai $t$ dari koefisien ab dengan rumusan sebagai berikut:

$$
t=\frac{\mathrm{ab}}{\mathrm{Sab}}
$$

Nilai t hitung ini dibandingkan dengan nilai t tabel dan jika nilai $t$ hitung lebih besar dari nilai tabel maka dapat disimpulkan bahwa terjadi pengaruh mediasi (Ghozali, 2016). Terdapat dua jenis pengaruh mediasi yakni mediasi penuh (full mediation) dan mediasi sebagian (partial mediation), dimana Full mediation ini menunjukan bahwa variable oksogen sepenuhnya dimediasi oleh mediator karena tidak ada lagi pengaruh langsung dari variable eksogen terhadap varibel ondogen.Sementara Partial mediatior menunjukan bahwa di samping memiliki pengaruh tidak langsung melalui mediator.Variable eksogen juga mempunyai mempunyai pengaruh langsung yang disignifikan pada variable endogen.Semua perhitungan dan analisis data dilakukan dengan menggunakan Sofrware Program SPSS versi 16 For Windows.

\section{HASIL ANALISIS DATA}

Berdasarkan tabel 4.2 di atas, dapat diketahui bahwa responden yang berusia dari 20 tahun sampai 25 tahun sebanyak 15 senioritas atau $31,58 \%$, usia lebih dari 26 tahun sampai 30 tahun sebanyak 15 senioritas atau $15,78 \%$, usia lebih dari 31 tahun sampai 35 tahun sebanyak 40 senioritas atau $42,52 \%$ usia lebih dari 36tahun sebanyak 10 senioritas atau $10,52 \%$.

Berdasarkan tabel 4.3 di atas, dapat diketahui bahwa responden yang SMA/Kejuruhansebanyak 40 tahun senioritas atau $42,10 \%$, yang Diploma sebanyak 22 tahun senioritas atau 23,16, dan yang Sarjana $\left(\mathrm{S}^{2}\right)$ sebanyak 25 tahun senioritas atau 26,32, dan yang Pasca sarjana sebanyak 8 thn senioritas atau 8,42.

\section{Uji Normalitas}

\begin{tabular}{|l|c|c|l|}
\hline \multicolumn{1}{|c|}{ Variabel } & $\begin{array}{l}\text { Kolmogoro } \\
\text { v_Smirnov } \\
\text { Z }\end{array}$ & Nilai Sig & Keterangan \\
\hline $\begin{array}{l}\text { Kualitas pelayanan } \\
\text { (X1) }\end{array}$ & 0,527 & 0,310 & $\begin{array}{l}\text { Berdistribusi } \\
\text { Normal }\end{array}$ \\
\hline $\begin{array}{l}\text { Kepercayaan merek } \\
(\mathrm{X} 2)\end{array}$ & 0,523 & 0,560 & $\begin{array}{l}\text { Berdistribusi } \\
\text { Normal }\end{array}$ \\
\hline Terhadap loyalitas (Y) & 0,539 & 0,2280 & $\begin{array}{l}\text { Berdistribusi } \\
\text { Normal }\end{array}$ \\
\hline $\begin{array}{l}\text { Kepuasan konsumen } \\
(\mathrm{Z})\end{array}$ & 0,513 & 0,920 & $\begin{array}{l}\text { Berdistribusi } \\
\text { Normal }\end{array}$ \\
\hline
\end{tabular}

Berdasarkan hasil pengujian normalitas pada table 4.11 diketahui bahwa nilai signifikansi residual yang terbentuk lebih besar dari taraf 0,05 
sehinggan dapat dikataqkan bahwa asumsi normalitas tersebut telah terpenuhi.

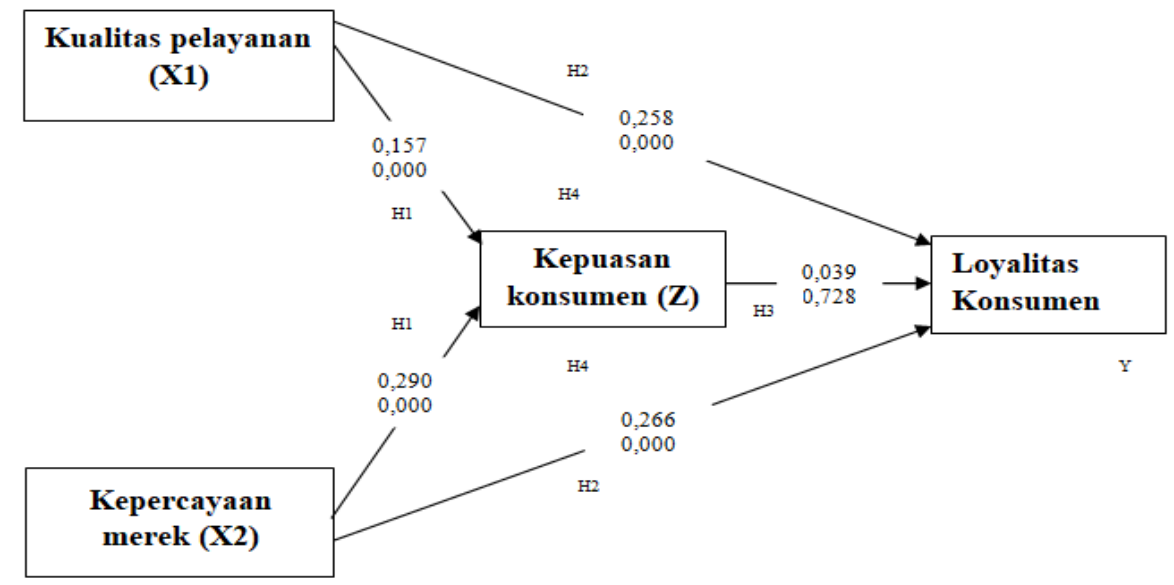

\section{Pengaruh Langsung (Direct Effect)}

\section{Hasil koefisien Jalur (uji Sobel)}

1) $\mathrm{H}_{1}=$ Pengaruh langsung variable kualitas pelayanan terhadap Kepuasan konsumen adalah sebesar $-15,7 \%$

2) $\mathrm{H}_{2}=$ Pengaruh langsung variable Kepuasan merek terhadap Kepuasan konsumen adalah sebesar $29 \%$

3) $\mathrm{H}_{3}=$ Pengaruh langsung variable Kepuasan konsumen terhadap Loyalitas konsumen sebesar $25 \%$

4) $\mathrm{H}_{4}=$ Pengaruh langsung variable kualitas pelayanan dan kepercayaan merek terhadap Loyalitas konsumen melalui kepuasan konsumen sebesar $26,6 \%$

\section{ANALISIS DATA}

\section{a. Model 1}

Hasil path Analysis Model

Coefficients $^{\mathrm{a}}$

\begin{tabular}{|l|r|r|rr|}
\hline \multirow{2}{*}{ Model } & \multicolumn{2}{|c|}{$\begin{array}{c}\text { Unstandardized } \\
\text { Coefficients }\end{array}$} & \multicolumn{2}{c|}{ Standardized Coefficients } \\
\cline { 2 - 5 } & \multicolumn{1}{|c|}{ B } & Std. Error & \multicolumn{2}{|c|}{ Beta } \\
\hline Constant) & 3,365 &, 422 & &,- 438 \\
X1 &,- 157 &, 065 & &, 400 \\
\hline
\end{tabular}

a. Dependent Variable: $Z$ (kepuasan konsumen) $Z=3,365+-0,438 X_{1}+0,400 X_{2}$

Hasil pemasaran regresi:

Nilai (bo) Sebesar 3,365 yang berarti apabila variabel (-) nilai variable kualitas pelayanan, kepercayaan merek maka kepuasan konsumen adalah 3,365

$B_{1}$ (nilai koefisien regresi $X_{1}$ ) $-0,438$ mempunyai arti bahwa kepercayaan berpengaruh neggatif terhadap kepuasan konsumen, jika semakain meningkat maka kepuasan meningkat.

$\mathrm{B}_{2}$ (nilai koefisien regresi $\mathrm{X}_{2}$ ) 0,400 mempunyai arti bahwa kepercayaan merek berpengaruh positif terhadap kepuasan konsumen. Artinya Jika semakin meningkat kepercayaan merek pada perusahaan maka kepuasan meningkat. 
b. $\quad$ Model 2

Hasil path Analysis Model 2

\begin{tabular}{|l|r|r|r|}
\hline \multirow{2}{*}{ Model } & \multicolumn{2}{|c|}{ Unstandardized Coefficients } & Standardized Coefficients \\
\cline { 2 - 5 } & \multicolumn{1}{|c|}{ B } & Std. Error & Beta \\
\hline X1. (Constant) & 2,386 &, 108 & \\
X2 &, 258 &, 017 &, 670 \\
X2 &, 266 &, 033 &, 343 \\
\hline a. Dependent Variable: Y (Loyalitas konsumen) & & \\
\hline
\end{tabular}

Sumber : data sudah di olah, 2019

Persamaan regresi model kedua pada tabel 4.13.adalah sebagai berikut:

$Y=2,386+0,670 X_{1}+0,343 X_{2}+4,781$

1. Nilai konstanta $\left(b_{\circ}\right)$ sebesar 2,386 yang berarti apabila nilai variable kualitas pelayanan, kepercayaan merek dan kepuasan konsumen adalah tetep (konstan), maka perubahan loyalitas konsumen adalah positif.

2. $B_{1}$ (nilai koefisien regresi $X_{1}$ ) mempunyai arti bahwa kualitas berpengruh positif terhadap loyalitas konsumen. Jika semakin besar kuallitas pelayanan untuk konsumen, maka loyalitas kinerja semakin meningkat.

3. $B_{2}$ (nilai koefisien regresi $X_{2}$ ) mempunyai arti bahwa kepercayaan merek berpengaruh positif terhadap loyalitas konsumen. Jika semakin baik kepercayaan merek pada perusahaan, maka loyalitas konsumenakan meningkat.

4. $\mathrm{B}_{3}$ (nilai koefisienregresi Z) mempunyai arti bahwa kepuasan konsumen berpengaruh positif terhadap loyalitas konsumen. Jika semakin kepuasan konsumen yang diberikan kepada konsumen, maka loyalitas konsumen akan meningkat.

\section{c. Model 3}

Hasil path Analysis Model 3

Coefficients $^{\mathrm{a}}$

\begin{tabular}{|c|c|c|c|c|c|c|}
\hline \multirow{2}{*}{\multicolumn{2}{|c|}{ Model }} & \multicolumn{2}{|c|}{$\begin{array}{l}\text { Unstandardized } \\
\text { Coefficients }\end{array}$} & $\begin{array}{c}\text { Standardized } \\
\text { Coefficients }\end{array}$ & \multirow[b]{2}{*}{$\mathrm{t}$} & \multirow[b]{2}{*}{ Sig. } \\
\hline & & $\mathrm{B}$ & Std. Error & Beta & & \\
\hline 1 & (Constant) & 4,781 &, 448 & & 10,674 &, 000 \\
\hline & Z & ,039, & , 111 & ,036 & ,348 & ,728 \\
\hline
\end{tabular}

a. Dependent Variable: (Kepuasan konsumen)

Hasil data path analiyss model 3 yang tampak pada tabel 4.14 diperoleh nilai beta variabel Kepuasan konsumen sebesar0,728 merupakan nilai $Z$ terdapat $Y$ $\mathrm{Y}=\beta_{5} \mathrm{Y}$ atau $\mathrm{Y}=0,728$

Keterangan :

$\mathrm{Y}=$ Kepuasan pelanggan

Hasil path analysis di atas memberikan pengertian bahwa $\beta_{7}$ (nilai koefisien beta Z) 0,728 memiliki pengertian bahwa Kepuasan konsumen mempunyai pengaruh positif terhadap loyalitas konsumen, jika Kepuasan konsumen meningkat maka loyalitas konsumen juga akan meningkat.

\section{PEMBAHASAN}

\section{a. Pengaruh kualitas pelayanan terhadap kepuasan konsumen}

Pengaruh antar variabel yaitu: $Z=-438$

Koefisien jalur kualitas pelayanan terhadap Kepuasan konsumen sebesar -438 artinya setiap peningkatan variabel kualitas pelayanan sebesar 1 satuan maka Kepuasan konsumen akan meningkat sebesar -438 kali. Kontribusi variabel Kualitas pelayanan terhadap Kepuasan 
Konsumen sebesar 0,017 artinya bahwa perubahan sebesar 0,017 pada Kepuasan konsumen disebabkan oleh perubahan Kualitas pelayanan.

\section{b. Pengaruh kepercayaan merek terhadap kepuasan konsumen}

Pengaruh antar variabel yaitu: $Y=0,400$

Koefisien jalur Kepercayaan merek Kepuasan konsumen sebesar 0,400 artinya setiap peningkatan Kepercayaan merek sebesar 1 satuan maka Kepuasan konsumen akan meningkat sebesar 0,400 kali. Kontribusi Kepercayaan merek terhadap Kepuasan konsumen sebesar 0,029 artinya bahwa perubahan sebesar 0,029 pada Minat Kepuasan konsumen disebabkan oleh perubahan kepercayaan merek.

\section{c. Pengaruh kualitas pelayanan terhadap loyalitas konsumen}

Pengaruh antar variabel yaitu: $Z=0,670$

Koefisien jalur Kualitas pelayanan terhadap Loyalitas konsumen sebesar 0,258 artinya setiap peningkatan variabel Kualitas pelayanan sebesar 1 satuan maka Loyalitas Konsumen akan meningkat sebesar 0,670 kali. Kontribusi variabel Loyalitas Konsumen terhadap Kualitas pelayanan sebesar $0,00 \%$ artinya bahwa perubahan sebesar $0,00 \%$ pada Loyalitas konsumen disebabkan oleh perubahan Kualitas konsumen.

\section{d. Pengaruh kepercayaan merek terhadap loyalitas konsumen.}

Pengaruh antar variabel yaitu: $Y=0,343$

Koefisien jalur Kepercayaan merek Kepuasan konsumen sebesar 0,343 artinya setiap peningkatan Kepercayaan merek sebesar 1 satuan maka Kepuasan konsumen akan meningkat sebesar 0,343 kali. Kontribusi Kepercayaan merek terhadap Kepuasan konsumen sebesar 0,000 artinya bahwa perubahan sebesar 0,000 pada Minat Kepuasan konsumen disebabkan oleh perubahan kepercayaan merek.

\section{e. Pengaruh kepuasan konsumen terhadap loyalitas konsumen.}

Pengaruh antar variabel yaitu: $Y=0,36$

Koefisien jalur Kualitas pelayanan terhadap Loyalitas konsumen sebesar 0,258 artinya setiap peningkatan Kualitas konsumen sebesar 1 satuan maka Loyalitas konsumen akan meningkat sebesar 0,036 kali. Kontribusi kualitas konsumenterhadap loyalitas konsumen sebesar 0,728 artinya bahwa perubahan sebesar 0,728 pada loyalitas konsumen disebabkan oleh perubahan kualitas konsumen. .

f. Pengaruh Kualitas pelayanan Terhadap kepuasan konsumen melalui loyalitas konsumen. 
Pengaruh antar variabel yaitu: $Y=0,438+0,036$

Koefisien jalur kepercayaan merek terhadap Loyalitas konsumen sebesar 0,438 artinya setiap peningkatan Kepercayaan merek sebesar 1 satuan maka Loyalitas konsumen akan meningkat sebesar 0,438 kali. Kontribusi Kepercayaan merek terhadap loyalitas konsumen sebesar 0,036artinya bahwa perubahan sebesar 0,036pada loyalitas konsumen disebabkan oleh perubahan kualitas konsumen.

\section{g. Pengaruh Kepercayaan merek Terhadap kepuasan konsumen melalui loyalitas konsumen.}

Pengaruh antar variabel yaitu: $Y=0,400+0,036$

Koefisien jalur kepercayaan merek terhadap Minat Loyalitas konsumen sebesar 0,400 artinya setiap peningkatan Kepercyaan merek sebesar 1 satuan maka Loyalitas Konsumen akan meningkat sebesar 0,400 kali. Kontribusi Kepercayaan merek terhadap Loyalitas Konsumen sebesar 0,036 artinya bahwa perubahan sebesar 0,036 pada Minat Loyalitas Konsumen disebabkan oleh perubahan Kepercayaan merek.

\section{SIMPULAN DAN SARAN}

Kualitas pelayanan, Dan kepercayaan merek Berpengaruh langsung terhadap Kepuasan konsumen

Hasil penelitian ini menunjukan bahwa kualitas pelayanan berpengaruh terhadap kepuasan konsumen diperoleh t-hitung $(2,436)$ yang lebih besar dari t-tabel $(1,980)$ atau signifikansi $(0,000)$ lebih kecil dari alpha $5 \%(0,050)$ maka disimpulkan terdapat pengaruh positif dan signifikan Kualitas pelayanan terhadap Kepuasan konsumen. Semakin baik kualitas pelayanan maka Kepuasan konsumen akan semakin meningkat atau sebaliknya semakin tidak baik kualitas pelayanan maka Kepuasan konsumen akan semakin menurun.

\section{Kualitas Pelayanan, Dan kepercayaan merek Berpengaruh langsung terhadap Loyalitas konsumen}

Hasil penelitian ini menunjukkan kualitas pelayanan berpengaruh terhadap Loyalitas konsumen diperoleh t-hitung $(15,530)$ yang lebih besar dari t-tabel $(1,980)$ atau signifikansi $(0,000)$ lebih kecil dari alpha $5 \%(0,050)$ maka disimpulkan terdapat pengaruh positif dan signifikan kualitas pelayanan terhadap Loyalitas konsumen. Semakin baik kualitas pelayanan maka Loyalitas konsumen akan semakin meningkat atau sebaliknya semakin tidak baik kualitas pelayanan maka Loyalitas konsumen akan semakin menurun.

\section{Kepuasan konsumen Berpengaruh langsung terhadap Loyalitas} konsumen

Hasil penelitian ini menunjukan bahwa Kepercayaan merek berpengaruh terhadap kepuasan konsumen diperoleh t-hitung $(2,223)$ yang lebih besar dari t-tabel $(1,980)$ atau signifikansi $(0,000)$ lebih kecil dari alpha $5 \%(0,050)$ maka disimpulkan terdapat pengaruh positif dan signifikan 
Kepercayaan merek terhadap kepuasan konsumen. Semakin baik kepercayaan merek maka kepuasan konsumen akan semakin meningkat atau sebaliknya semakin tidak baik kepercayaan Merek maka kepuasan konsumen akan semakin menurun.

\section{Kualitas Pelayanan dan Kepercayaan merek secara tidak langsung Berpengaruh terhadap Loyalitas konsumen dengan Kepuasan konsumen}

Hasil pengujian pengaruh tidak langsung kualitas pelayanan terhadap Lolayalitas konsumen melalui Kepuasan konsumen dipeoleh thitung $(3,833)$ yang lebih besar dari t-tabel $(1,9852)$ atau signifikansi $(0,000)$ lebih kecil dari alpha 5\% $(0,050)$ maka disimpulkan terdapat pengaruh tidak langsung yang signifikan dengan arah positif antara kepuasan konsumen terhadap Loyalitas konsumen melalui Kepuasan konsumen. Artinya, apabila kepuasan konsumen semakin baik diikuti dengan Kepuasan konsumen yang semakin tinggi maka loyalitas konsumen akan semakin meningkat. Sebaliknya apabila Kepuasan konsumen semakin tidak baik diikuti dengan Kepuasan Konsumen yang semakin rendah makaLoyalitas konsumen akan semakin menurun.

Hasil pengujian pengaruh tidak langsung kepercayaan merek terhadap Lolayalitas konsumen melalui Kepuasan konsumen dipeoleh thitung $(2,006)$ yang lebih besar dari t-tabel $(1,9852)$ atau signifikansi $(0,000)$ lebih kecil dari alpha 5\% $(0,050)$ maka disimpulkan terdapat pengaruh tidak langsung yang signifikan dengan arah positif antara kepuasan konsumen terhadap Loyalitas konsumen melalui Kepuasan konsumen. Artinya, apabila kepuasan konsumen semakin baik diikuti dengan Kepuasan konsumen yang semakin tinggi maka loyalitas konsumen akan semakin meningkat. Sebaliknya apabila Kepuasan konsumen semakin tidak baik diikuti dengan Kepuasan Konsumen yang semakin rendah makaLoyalitas konsumen akan semakin menurun.

\section{DAFTAR PUSTAKA}

Ali Hasan. 2008. Marketing. Jakarta : PT. Buku Kita.

Achmad Kuncoro, Engkos, Dan Riduan, 2008 Cara menggunakan dan memaknai Analisis Jalur. Bandung: Alfabeta.

Akdon, Riduwan, 2001, Rumus dan Data dalam Aplikasi Statistika. Bandungg Alfabeta.

Baskara, Isnain Putra dan Guruh Taufan Hariyadi. 2014. Analisis Pengaruh Kepercayaan, Keamanan, Kualitas Pelayanan dan Persepsi akan Resiko terhadap Keputusan Pembelian melalui jejaring social. Universitas Dian uswantoro. Semarang.

Chen, S. C. \& Dhilon, G. S. 2003. Interpreting Dimensions of Costumer Trust in e Commerce, information Technology and Management, 4,203-318.

Featherman, dan pavlou., 2002, Predicting E-Service Adoption: A Perceive Risk FacetsPerspective, Internasional jounal of Human-Computer Studies, 59 (04), 1034-1046.

Griffin, Jill. 2005. Customer Loyality: Menumbuhkan dan Mempertahankan Kesetiaan Pelanggan. Jakarta: Erlangga. 
Ghozalii, Imam. 2011, "Aplikasi Analisis Multivariate Dengan Program SPSS". Semarang: Badan Penerbit Universitas Diponegoro.

Hasan, A. 2008. Marketing. Yogyakarta: Medja Pressindo

Hurriyati, Ratih. 2013. Bauran Pelayanan dan Loyalitas Konsumen. Bandung : Alfabeta

Istianto, Jhon Hendra \& Tyra Maria Josephine. 2011. Analisis pengaruh kualitas layanan terhadap kepuasan pelanggan. Jurnal Ekonomi dan Informasi Akuntansi.

Rangkuti. 2004. Riset Pemasaran, Catakan Kelima, Jakarta: PT. Gramedia Pustaka Utama. Hawkins dan Looney. 2003. "Marketing Dalam Pemasaran Jasa”. Jakarta: Indeks.

Kotler, Philip dan Gary Armstrong (2004). Principles of Marketing. $10^{\text {th }}$ Ed. New Jersey: Pearson Prentice Hall.

Kotler, Philip dan Kevin Lane Keller, 2007, Manajemen Pemasaran, Jakarta, edisi.

Kotler, Philip dan Kevin Lane, Keller. 2009. Manajemen Pemasaran. Jilid 1 dan 2.Edisi 13. Jakarta: Erlangga.

Kotler, Philip, \& Kevin Lane Keller. 2009. Manajemen Pemasaran Jilid 2. Edisi 13. Alih Bahasa. Jakarta: Erlangga

Kotler dan Keller. 2012, Manajemen Pemasaran. Jilid 1. Alih Bahasa oleh Bnyamin Molan, Edisi 12. Jakarta: PT Indeks.

Kotler, dan Keller, 2012. Manajemen Pemasaran 12. Jakarta: Erlangga.

Lovelock, C., et al., .2010. Pemasaran Jasa. Jakarta: Erlangga.

McKninght, D. Harrison, et, al 2002. Developing and Validating Trust Measure for E-Commerce: An Integrative Typology. Informastion System Research. Vol. 13,334-359.

Mayer, R.C., et al.al 2007. " An Integratif Model of organizational trust: Past, Present, and future, "Academy of Manajement review, 32 (2),344354.

Nutbisi, Nelson O. 2007. Relationship Marketing and Customer Loyalty. Marketing Intelligence and Planning. Vo; 25. No.1. pg 96-106

Park, Chung-Hoon.m et. al 2006 the Effect of Information satisfaction anda Relational benefit on Commitmennts, Journal of Electronic Commerce in Organizations, 4 (1),70-90.

Pavlou, P.A., et. al. 2002. Building Effective Online Marktplaces with institution-based Trust, Proceedings of Twenty-third International Conference on Information Systems, 667-675.

Rambat, Lumpiyadi dan Hamdani, A., 2009. Manajemen Pemasaran Jasa, Jakarta:PT. Salemba Emapat.

Ruparelia, N., White, L., and Hughes, Kate. 2010. Drivers Of Brand Trust In Internet Retailing. Journal Of Product \& Brand Management, 19(4):250-260

Sukma Adi. A. 2012. Analisis factor-faktor yang mempengaruhi Keputusan Pembelian Melalui Sosial Networking Websites. JUrnal Ekonomi Unirvitas Gunadarma. Vol. 1, hal 1-11

Sutopo Dn Suryanto, Andi. 2003. Pelayanan Prima. Jakarta: Lembaga Administrasi Negara rebublik Indonesia. 
Sutopo, 2006. Pinsip prinsip Pemasaran, edisikedua, Yogyakarta: UST Press.

Sangadji, Etta Mamang \& Sopiah. 2013. Perilaku Konsumen - Pendekatan

Praktis disertai Himpunan Jurnal Penelitian. Yogyakarta: ANDI.

S, Arikunto,. 2013. Produser Peneltian Suatu Pendekatan Praktik. Jakarta:

Rineka CiptaBand, William A, 1991. Crafeting Value for Custumer, Jhon Willey and Sons Ins, New York.

Sugiyono 2006, Metode Penelitian Administrasi, Penerbit Alfabeta Bandung Sugiyono. 2000, Statistika untuk Penelitian, Bandung: Alfabeta.

Sugiyono 2013. Metode Penelitian Pendidikan Pendekatan Kuantitatif, Kualitatif, dan R\&D. Bandung: Alfabeda.

Sugiyono. 2010. Metode Penelitian Pendidikan PendekatanKuantitatif, Kualitatif, dan R\&D. Bandung: Alfabeta.

Sugiyono. 2004. Metode Penelitian. Bandung: Alfabeta

Sugiyono. 2008. Metode Penelitian Kuantitatif Kualitatif dan R\&D. Bandung: Alfabeta

Suryani, Tatik. 2008. Perilaku Konsumen; Implikasi pada Strategi Pemasaran. Yogyakarta: Graha IImu.

Tjiptono, Fandy. 2011. Pemasaran Jasa. Yogyakarta : Penerbit ANDI. 2014. Pemasaran Jasa. Yogyakarta : Penerbit ANDI.

Tjiptono, Fandy, 2011, PemasaranJas, Bayumedia, Malang.

Umar, Husein. 2008. Metode Riset Bisnis. Jakarta: PT. Gramedia Pustaka Utama

Zeithaml, Valerie A., Mary Jo Bitner \& Dawayne D. Gemler. 2013. Service Marketing Integrating Customer Focus Across the Firm. 4thed. Mc. New York : Graw Hill.

Zeithaml. VA. Bitner MJ. 1996. Delivering and Performing Service. Part Five Across The Firm. $3^{\text {rd }}$ Edition. Boston: McGraw HII/Irwin.

Zeithaml, Valarie A. Mry Jo Bitner. (2000). Service Marketing: Integrating Customer Focus Across The Firm, Second Edition Hill. New York: McGra.

WIKIPEDIA. 2014. Internet. Diunduh dari http://id.wikipedia.org/wiki/internet pada tanggal 22 November 2018.

http://www.andriewongso.com/artikel/aw_artikel/1443/Nilai_Sebuah_Keper cayaan/s 